\title{
Analysis of the export growth impetus of Chinese forest chemical products
}

\author{
Mi Zhou, a, Li Huang ${ }^{2, b}$ \\ ${ }^{1}$ College of Economics and Management; Shenyang Agricultural University, Shenyang China \\ ${ }^{2}$ Information Center of Liaoning Province Commission of Rural Economy, Shenyang China \\ adhtzor@163.com, bhuanglixxzx@163.com
}

Keywords: forest chemical product; modified CMS model; export; influencing factor; NWFP

\begin{abstract}
Using a modified Constant Market Share (CMS) model, this paper analyzes the changes, causes, and inherent mechanisms of major Chinese forest chemical product exports during 1992-2011. The analysis shows the rapid growth of such exports due mainly to increasing demand from the international market and the enhancement of the products' competitiveness. Further, the market distribution of Chinese forest chemical products in the main sample of the research is shown to be constantly improving; that is, the structure of the export target market of the products is constantly optimizing. In addition, during the period of analysis Japan was the largest importer of major Chinese forest chemical products, but the competitiveness of the products in the Japanese market decreased significantly in recent years.
\end{abstract}

\section{Introduction}

Chinese timber has been in short supply for some time because of the lack of forest resources. Consequently, the government has had to use large sums of foreign exchange to import all kinds of wooden forest products. In the past 20 years, the Chinese government has paid particular attention to the non-wood forest products (NWFPs) trade.

Forest chemical products are important NWFPs around the world. In China, the resources of the forest chemical industry are very rich and the chemical processing of forest products has already provided a relatively complete product range. In fact, in recent decades, Chinese forest chemical products have developed from approximately 20 varieties to more than 100 (SFA 2008). By investigating the area structure of the main forest chemical products in 2002-2005, we found that China was the world's largest exporter of rosin, activated carbon, turpentine, and camphor during this period, and that these products' shares of world exports were $57.9 \%$, 22\%, 20\%, and $71.4 \%$ respectively (Huang et al. 2007), which shows that the products are of special importance in the international market.

This paper takes rosin, activated carbon, turpentine, and camphor, the four main exported Chinese forest chemical products as its research objects. Between 1992 and 2011, China's export of these four products increased rapidly, with total exports rising from 0.171 billion dollars to 1.008 billion dollars at an average annual growth rate of $22.76 \%$. Our interest here lies in what has caused this significant growth. Further, many factors affect the export of Chinese forest chemical products; therefore, we wish to determine the impact of these various influencing factors. This paper analyzes the degree to which various factors affect the export growth of China's major forest chemical products using a modified CMS model. It then tests the rationality of export product structure and market distribution, both of which have a certain reference value to international competition strategy and trade policy making with regard to China's forest chemical products. 


\section{Data}

The China Customs Statistical Yearbook started to use the statistical caliber of "Coordinated Code" from 1992. To achieve data uniformity, this paper takes major Chinese forest chemical products trade data from 1992 2011 as its research basis and obtains the data from the United Nations COMTRADE Database. This paper also uses HS1992 classifications. The codes for rosin, activated carbon, turpentine, and camphor are 380610, 380210, 380510, and 291421 respectively.

\section{Analysis of the international competitiveness factors that affect major Chinese forest chemical products}

In this section, the paper analyzes the causes behind the export growth of China's main forest chemical products by using the modified CMS model, and then tests the rationality of export product structure and market distribution. The selected sample markets are Japan, Portugal, South Korea, India, the United States, Holland, France, Germany, Spain, and Thailand. In the past 20 years, the import value of major forest chemical products in these 10 sample areas accounted for $55-70 \%$ of total global import value, while the export value of the products to these regions accounted for about $70 \%$ of China's total export value. Therefore, the sample markets are strongly representative. The time span of the sample data was 1992 to 2011. With regard to the determination of the time segment, the CMS model usually puts the years with similar data characteristics into one group, and uses the average value of these years' data for calculation. In accordance with Figure 1, we put 1992 to 1995 into the first phase; during this period, the exports of China's main forest chemical products were between 150 and 200 million dollars. We placed 1996 to 2004 into the second phase when exports of China's main forest chemical products were between 200 and 300 million dollars. In 2005, the export value increased to 406 million dollars and remained at around 500 million dollars over the next few years; therefore, we put 2005-2009 into the third phase. In 2010, the export value soared to 800 million dollars and rose to 1 billion dollars in 2011. We therefore speculated that China's main forest chemical product exports had entered a period of rapid development and used 2010 to 2011 as the fourth phase. The average data of the four phases were calculated in the model.

Table 1 The effect decomposition of Chinese forest chemical product exports from 1992 to 2011

\begin{tabular}{|c|c|c|c|c|c|c|}
\hline \multirow{2}{*}{ Effect decomposition } & \multicolumn{2}{|c|}{$\begin{array}{c}\text { Phase } 1 \text { to Phase } 2 \text { (the } \\
\text { first period) }\end{array}$} & \multicolumn{2}{|c|}{$\begin{array}{l}\text { Phase } 2 \text { to Phase } 3 \text { (the } \\
\text { second period) }\end{array}$} & \multicolumn{2}{|c|}{$\begin{array}{c}\text { Phase } 3 \text { to Phase } 4 \text { (the } \\
\text { third period ) }\end{array}$} \\
\hline & $\begin{array}{c}\text { Contributio } \\
\text { n value }\end{array}$ & $\begin{array}{l}\text { Contribut } \\
\text { ion rate }\end{array}$ & $\begin{array}{l}\text { Contribution } \\
\text { value }\end{array}$ & $\begin{array}{c}\text { Contributio } \\
\text { n rate }\end{array}$ & $\begin{array}{c}\text { Contribution } \\
\text { value }\end{array}$ & $\begin{array}{l}\text { Contributi } \\
\text { on rate }\end{array}$ \\
\hline Total effect & 0.71 & 100 & 2.5 & 100 & 4.07 & 100 \\
\hline Market scale effect & 0.82 & 115.49 & 1.33 & 53.20 & 3.10 & 76.17 \\
\hline Product structure effect & -0.11 & -15.49 & -0.1 & -4.00 & 0.21 & 5.16 \\
\hline $\begin{array}{l}\text { Market distribution } \\
\text { effect }\end{array}$ & 0.07 & 9.86 & 0.02 & 0.80 & 0.13 & 3.19 \\
\hline $\begin{array}{c}\text { Product } \\
\text { competitiveness effect }\end{array}$ & 0.05 & 7.04 & 0.69 & 27.60 & 0.28 & 6.88 \\
\hline $\begin{array}{c}\text { Market } \\
\text { competitiveness effect }\end{array}$ & -0.12 & -16.90 & 0.57 & 22.80 & 0.35 & 8.60 \\
\hline
\end{tabular}

As shown in Table 1, in the second phase, the average annual export value of China's forest chemical products increased by 71 million dollars compared with the first phase. This growth can be decomposed into four parts. The first is the positive market scale effect, the results of which show that this was 82 million dollars with a contribution rate of $115.49 \%$. This means that the demand for forest chemical products in the world market was increasing. During 1992-1995, the average import value of forest chemical products in the world market was 673 million dollars, while that of 1996-2004 amounted to 988 million dollars. Thus, the continued demand growth of the 
global market for forest chemical products drove Chinese forest chemical product exports. The second part is the negative product structure effect, which was - 11 million dollars with a contribution rate of $-15.49 \%$. A negative product structure effect illustrates that the commodity structure of Chinese exports was not very reasonable relative to that of the world's exports and that Chinese exports did not concentrate on products with fast demand growth. The import growth rate of rosin in the world market was $26.56 \%$ and the rates of active carbon, turpentine, and camphor were 66.46\%, 51.72\%, and 37.5\%, respectively. During this period, Chinese exports concentrated mainly on the rosin market, which accounted for $60 \%$ of the total exports of China's forest chemical products. The third part is the positive market distribution effect, the total contribution value and contribution rate of which were 7 million dollars and 9.86\% respectively. We find that the market distribution effects of Portugal and India were positive, while those of the remaining samples were all negative, which indicates that the import growth rate of Chinese forest chemical products in these areas was less than that of the world average growth rate. Because the market distribution effect in other markets was positive, the overall market distribution effect was positive. The fourth part is the competitiveness effect, the total contribution value of which was -7 million dollars and the total contribution rate was $-9.86 \%$. In this regard, the market competitiveness effect was -12 million dollars, and the competitiveness effect of Chinese forest chemical products in other markets was -66.7 million dollars, which shows that Chinese forest chemical products were not competitive in other export markets. The product competitiveness effect was 5 million dollars, of which activated carbon showed strong competitiveness while the competitiveness effects of turpentine and camphor products were not obvious, and that of rosin was negative.

In the third phase, the average annual export value of Chinese forest chemical products increased by 250 million dollars compared with the second phase. In addition, compared with the first period, the market scale effect and market distribution effect were still positive but the contribution rates decreased by $62.29 \%$ and $9.06 \%$ respectively. On one hand, this shows that the driving effect of global demand for forest chemical products on Chinese exports decreased; on the other hand, although the contribution rate of the market distribution effect reduced, the market distribution situation of the main sample markets improved compared with the first period: only the United States, Japan, Holland, and Germany still had negative market distribution effects, the rest of the samples all had positive effects. At the same time, the market distribution effect of Chinese forest chemical products in other markets turned from positive in the first period to negative, reflecting a situation in which the market structure of Chinese forest chemical product exports was more reasonable during the second period. Compared with the first period, the contribution rates of the product structure and competitiveness effects increased. The former rose from $-15.49 \%$ to $-4 \%$, and the product and market competitiveness effects increased by $20.56 \%$ and $38.98 \%$ respectively. Further, the market competitiveness effect changed from negative to positive. In the second period, the product structure effect was still negative, although the negative influencing extent lightened, and the product competitiveness effect was 69 million dollars, of which activated carbon maintained strong competitiveness. In addition, the competitiveness effect of rosin changed from negative in the first period to positive, while the competitiveness effects of turpentine and camphor products were inconspicuous. The competitiveness effect of Chinese forest chemical products in other markets changed from -0.667 to 0.54 , which made the total market competitiveness effect change from negative to positive. This shows that, in addition to sample markets, Chinese forest chemical products in the second period had strong competitive power in other export markets.

In the fourth phase, the average annual export value of Chinese forest chemical products increased by 407 million dollars compared with the third phase. We can see from Table 5 that the 
four effects of the third period were all positive and that the contribution rates were $76.17 \%, 5.16 \%$, $3.19 \%$, and $15.48 \%$. This driving effect of the world market's demand for forest products on Chinese forest chemical product exports in this period became greater compared with the effect in the second period. As the world market's demand for rosin soared, the export structure of Chinese forest chemical products was improved, which made the product structure effect become positive. In the third period, the market distribution effect of Chinese forest chemical products in the country's main sample markets improved further, indicating that optimizing the export target market structure of such products to a greater extent may still cause their export value to increase. At the same time, active carbon and rosin continued to maintain strong competitiveness. It is worth noting that the market competitiveness effect of Chinese forest chemical products in the markets of Japan, the United States, and Holland changed from positive to negative, and that the most obvious decline happened in Japan.

\section{Conclusion}

This paper discussed the influencing factors on Chinese forest chemical product exports through the Constant Market Share model. From the empirical analysis results, we find that the market scale effect played a major role in Chinese forest chemical product exports from 1992 to 2011. The commodity structure of such exports was not ideal relative to that of the world; however, because of the increasing demand for rosin from the world market in recent years of the analysis, the export structure of Chinese forest chemical products improved. Further, the market distribution situation of such products in the main sample improved constantly; that is, the structure of the export target markets for Chinese forest chemical products was constantly optimizing. In addition, one limitation of the study is that the data is specific to the Chinese market and as such cannot be generalized. Nonetheless, other researchers could use the modified CMS model to explore influencing factors on the forest chemical product exports of other countries. In this way, it also help to validate the significance of this model.

\section{Acknowledgements}

This work was supported by the National Science Foundation of China(NO.71203146; NO.71273179; NO.71373163; NO.71273177), the program for excellent talents in Liaoning province (NO.WJQ2014016); and agriculture youth science and technology innovation talent training plan in Liaoning province (NO.2014055).

\section{References}

[1]Huang L, Fang TK, Lv J. (2007) Analysis of Chinas Terms of Trade and Worlds Region Structure of Forest Chemical Products.Forestry Economics issues 4:33-37.

[2]SFA (2008) Chinese Forestry Development Report.China Forestry Publishing House, Peking (in Chinese)

[3]Zhang H, Nie Y. (2010) Analysis on the motivation of export growth of Chinese forest products:1997-2008. Chinese Rural Economics 1:35-44.

[4]Zhang ZT, Luo XJ. (2012) Analysis on the trade of Chinese forest products. Forestry Economics 8: 29-35. 